\title{
Modelling the behavior of fiber-reinforced concrete with low-modulus fibers under load
}

\author{
Yury V. Pukharenko', Dmitrii A. Panteleev ${ }^{1,{ }^{*}}$, Mikhail I. Zhavoronkov ${ }^{1}$, Maxim P. \\ Kostrikin ${ }^{1}$, and Said Mujtaba Eshanzada ${ }^{2}$ \\ ${ }^{1}$ Saint Petersburg State University of Architecture and Civil Engineering, Department of Technology \\ of Construction Materials and Metrology, Saint-Petersburg, Russia. \\ ${ }^{2}$ Polytechnical University of Kabul, Kabul, Afghanistan.
}

\begin{abstract}
In this work was carried out a study the purpose of which was the development of physical and mechanical modeling of the processes of deformation and destruction of fiber-reinforced concrete. The process of deformation and the mechanism of destruction of fiber-reinforced concrete reinforced with low-modulus polypropylene fibers have been investigated. The method has been improved and the characteristic of adhesion of polypropylene fiber to the matrix has been determined. Theoretical models for forecasting the behavior of fiber-reinforced concrete reinforced with polypropylene fiber under load have been developed.
\end{abstract}

\section{Introduction}

The most important quality of fiber-reinforced concrete as a composite material is its high crack resistance, for the assessment of which power and energetic characteristics are used [13].

Taking into account the experience of previous studies, the device and method for testing the crack resistance of fiber-reinforced concrete were improved, according to which the process of constructing diagrams of the destruction of fiber-reinforced concrete samples was automated, and the preliminary preparation of samples for testing was greatly simplified [4]. An increase in the accuracy of control of the deflections of the tested samples and a decrease the speed of application of the load facilitated the determination of the coordinates of the most important point $\mathrm{T}$ on the diagrams of deformation the fiber-reinforced concrete samples.

Previous studies have determined the power and energetic characteristics of the crack resistance of fiber-reinforced concrete made with steel wire fiber and established the degree of influence of quantity of fiber on these characteristics and flexural strength. For the further develop of this direction, in this work, using the developed device, the characteristics and properties of fiber-reinforced concrete made with low-modulus polypropylene fibers to obtain reliable statistical data were studied. The accumulation of such information allows to get a more complete picture of fiber-reinforced concrete, and simplifies the substantiation for choosing the type of fiber for the design of fiber-reinforced concrete products and structures.

\footnotetext{
* Corresponding author: $\underline{\mathrm{dm}-\mathrm{pant} @ \text { yandex.ru }}$
} 


\section{Materials used}

All experimental studies were carried out on samples with dimensions $7 \times 7 \times 28 \mathrm{~cm}$, according to the requirements of GOST 29167 «Concrete. Methods for determining the characteristics of crack resistance (fracture toughness) under static loading». Together with the fiberreinforced concrete samples, unreinforced concrete samples made of the same matrix composition were also made. This approach makes it possible to evaluate the effect of only the parameters of fiber reinforcement on the properties of the composite. In the manufacture of samples, fine-grained concrete was used as a matrix, which made it possible to achieve a high degree of dispersion of the reinforcement. The composition of the concrete mixture of all samples was the same: Cement : Sand $=1: 2$ at Water/Cement ratio $=0,35$ and the quantity of the superplasticizer addition «Macromer P-17» was $0,5 \%$ of the mass of Portland cement. For preparation the samples were used quartz sand with a fineness modulus 2,3 in accordance with GOST 8736 «Sand for construction work» and Portland cement CEM I 42,5 N produced by HeidelbergCement (Cement Plant CESLA). Mixtures were compacted on a laboratory vibrating platform. Freshly formed samples were kept for strength gain in a normal hardening chamber at a temperature of $(20 \pm 2)^{\circ} \mathrm{C}$ and a relative humidity of $(95 \pm 5) \%$.

For reinforcement, synthetic polypropylene fiber was used (Fig. 1), the length of which was $12 \mathrm{~mm}$, diameter $-0,025 \mathrm{~mm}$, and the modulus of elasticity of the material of these fibers was $9000 \mathrm{MPa}$.

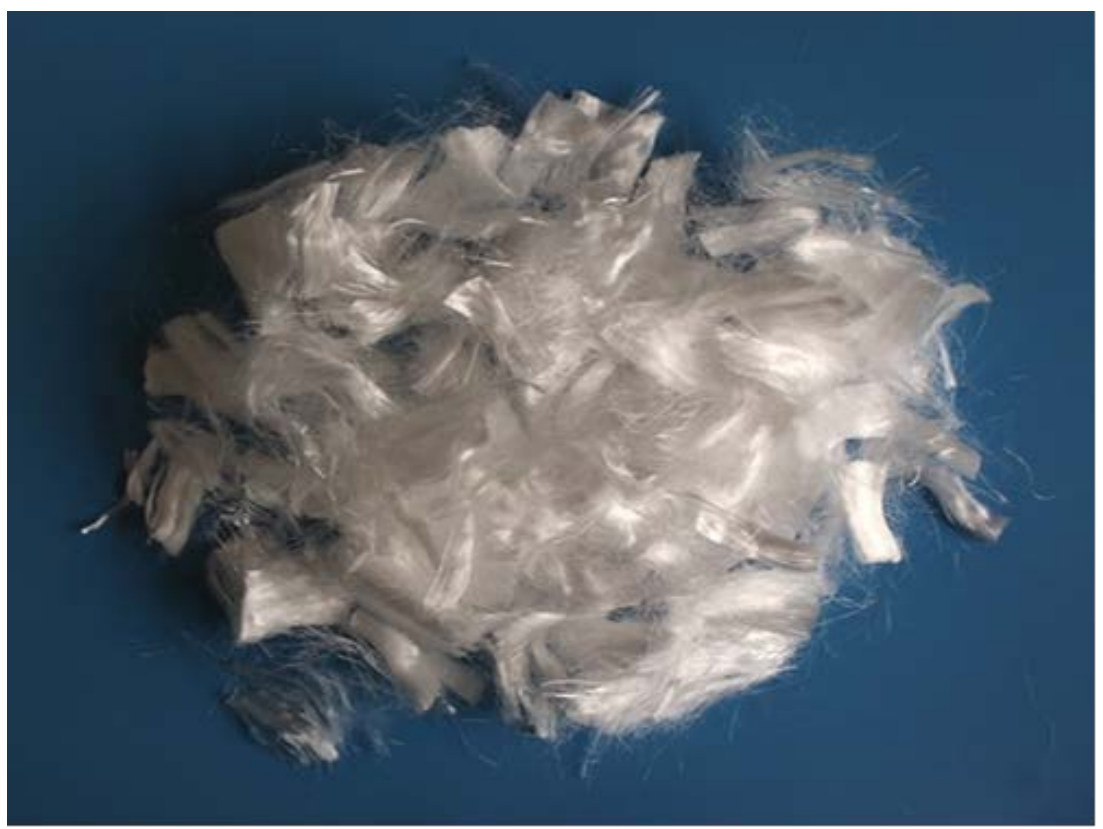

Fig. 1. Synthetic polypropylene fiber.

\section{Main results and their analysis}

Figures 2 and 3 show the complete diagrams of deflections depending on the applied loads, drew during the testing of samples, and their sections describing the elastic deformation zone. 


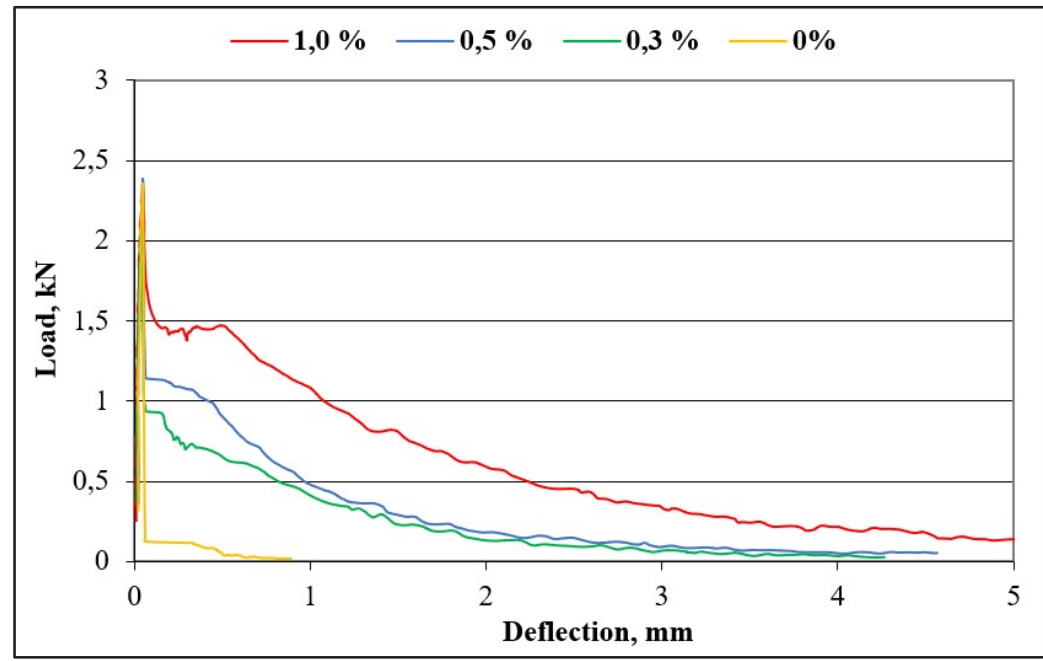

Fig. 2. Complete diagrams of destruction of fiber-reinforced concrete samples.

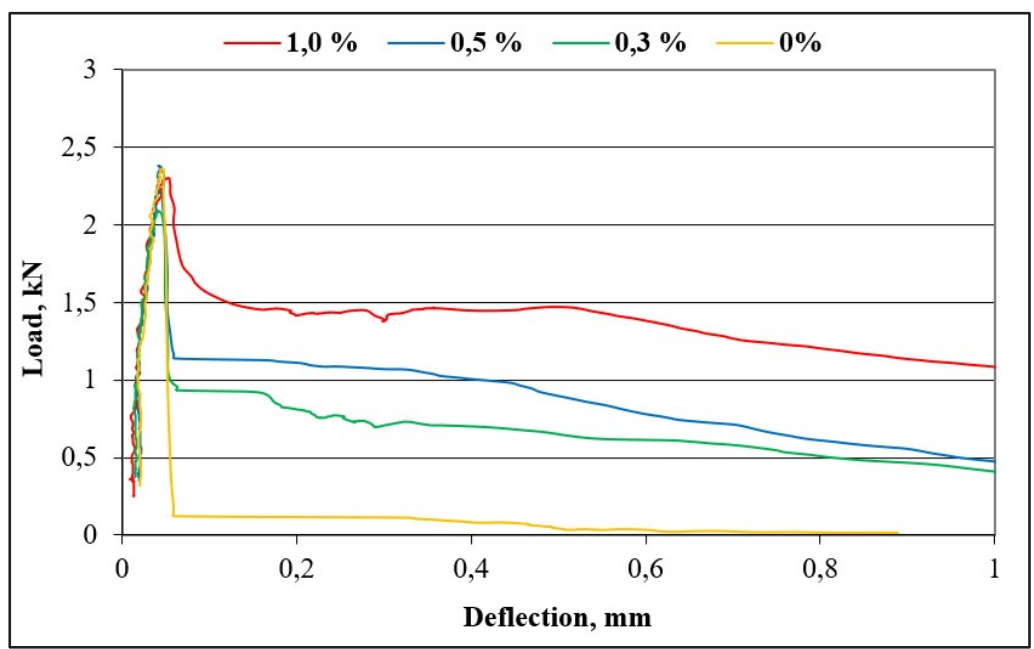

Fig. 3. Elastic deformation areas of destruction diagrams of fiber-reinforced concrete samples.

The graphs shown in figure 3 show that the deflections of the samples at the stage of elastic deformation under the same loads are different, while, despite the fact that the polypropylene fiber is low modulus, the modulus of elasticity of the composite slightly increases after its adding. The loads corresponding to the moment of starting the movement of main cracks in the samples differ insignificantly, what is also explained by the use of fibers with a low elastic modulus for reinforcement, which do not affect significantly on the behavior of fiber-reinforced concrete under load at this stage of deformation. This follows both from the values of the energy consumption recorded before the beginning of the movement of the main crack, and from the values of the critical stress intensity factor.

Observed in this case a slight increase in the elastic modulus of fiber-reinforced concrete can be explained by the modification of the structure of the cement stone near the surface of the fibers, which have a small diameter, relatively short length, what provides a high degree of dispersion of the reinforcement, that is a very extended interface with the matrix. All of this leads to the creation of a developed micro-framework, created by contact zones with 
increased density and hardness. Such frame, as in the case of using other types of fiber, prevents the development of deformations $[5,6]$.

When the maximum stresses are reached, polypropylene fibers lose their adhesion with the matrix and are pulled out of it, which is accompanied first by an increase and then a decrease in the load and is described by the corresponding branch of the diagram. Numerically, this process is characterized by conditional specific effective energy consumption for static destruction $\left(G_{f}^{*}\right)$.

The diagrams show that the volumetric content of polypropylene fiber does not change the nature and mechanism of destruction of fiber-reinforced concrete, and only influence on the numerical values of the characteristics of crack resistance and elastic modulus.

Table 1 shows the numerical values of the characteristics of crack resistance and elastic modulus of the tested samples.

Table 1. Characteristics of crack resistance and elastic modulus of fiber-reinforced samples.

\begin{tabular}{|c|c|c|c|c|}
\hline \multirow{2}{*}{ Crack resistance characteristic } & \multicolumn{4}{|c|}{ Volumetric content of fiber, \% } \\
\cline { 2 - 5 } & 0 & 0,3 & 0,5 & 1,0 \\
\hline $\begin{array}{c}G^{*}{ }_{i}-\text { conditional specific energy } \\
\text { consumption for static destruction until the } \\
\text { moment the main crack starts to move, } \mathrm{J} / \mathrm{m}^{2}\end{array}$ & 20,6 & 16,3 & 20,6 & 23,3 \\
\hline $\begin{array}{c}G^{*}{ }_{f}-\text { conditional specific energy } \\
\text { consumption for static destruction, } \mathrm{J} / \mathrm{m}^{2}\end{array}$ & 34,3 & 330,2 & 435,4 & 933,8 \\
\hline$K^{*}{ }_{c}-$ conditional critical stress intensity $_{\text {factor, MPa· }{ }^{0,5}}$ & 0,79 & 0,71 & 0,79 & 0,76 \\
\hline Flexural strength, MPa & 6,2 & 5,9 & 6,5 & 6,1 \\
\hline Elastic modulus, MPa*10 & 36,2 & 37,6 & 36,8 & 39,9 \\
\hline
\end{tabular}

Despite the fact that it was possible to obtain experimental data that fairly accurately show the behavior of fiber-reinforced concrete under load, testing, even with the use of a special device, remains a very laborious process, therefore the development of methods for theoretical prediction of the desired characteristics becomes actual.

As a result of the experiments, it became possible to establish the general view of the deformation diagram of fiber-reinforced concrete specimens [7-9], reinforced with lowmodulus polypropylene fibers (Fig. 4).

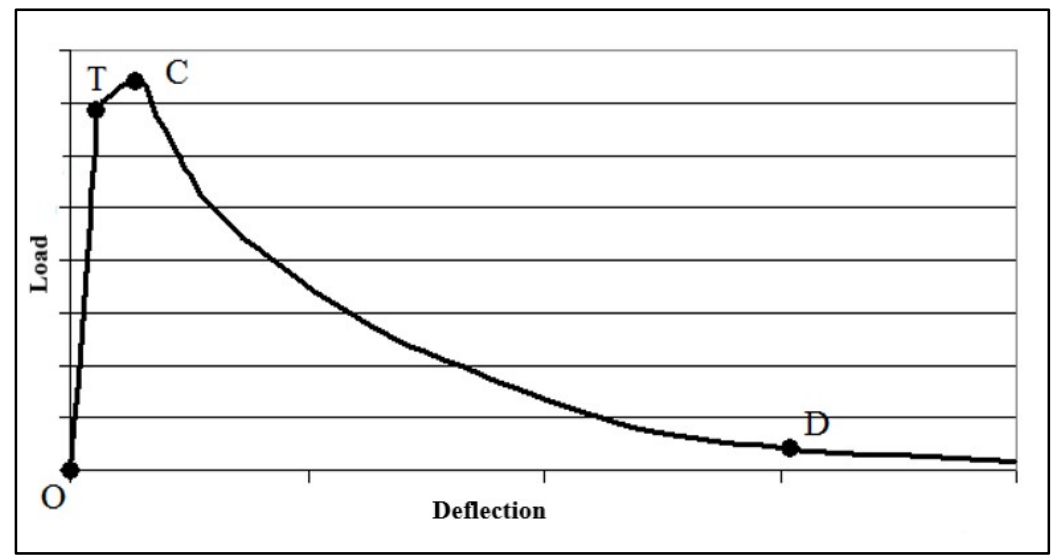

Fig. 4. General view of the deformation diagram of a fiber-reinforced concrete sample reinforced with low-modulus synthetic fibers. 
Figure 4 shows that the diagram has three specific sections within the corresponding segments OT, TC and CD. Wherein, point T limits the zone of elastic deformations, point $\mathrm{C}$ corresponds to the end of the growth of the main crack and can correspond to the maximum value along the load axis, point $\mathrm{D}$ determines the amount of sample deflection at the moment of failure (end of the test). Thus, to build the estimated diagram of the deformation of a fiberreinforced concrete specimen under load up to failure, it is necessary to determine the coordinates of points $\mathrm{T}, \mathrm{C}$, and D, which will correspond to the loads (along the vertical axis) and deflection deformations (along the horizontal axis) at these points.

The process of building an estimated deformation diagram should be started from the OT line, which limits the elastic deformation zone. It is known that such deformations are characterized by a straight line, the angle of which depends on the elastic modulus of the material.

It is obvious that microcracking in fiber-reinforced concrete begins at the same deflections as in the unreinforced sample, which, according to the available information, are in the range of $0,03-0,04 \mathrm{~mm}$ [9]. In this case, the load, and accordingly the location of the point $\mathrm{T}$, can be determined by the formula (1):

$$
P_{T}=\frac{f_{T} 48 E_{f b} I}{l_{o}^{3}}
$$

where $P_{T}$ - the load acting on the sample; $f_{T}$ - deflection corresponding to point T; $I-$ moment of inertia; $l_{o}$ - sample base (distance between supports); $E_{f b}$ - elastic modulus of fiber-reinforced concrete.

The elastic modulus of fiber-reinforced concrete can be determined by calculation using formulas that represent the development of one of the well-known laws of the theory of composite materials - the «rule of mixtures», and connecting the elastic modulus of all components that make up fiber-reinforced concrete with their content in the sample volume. However, this approach, like other similar ones, does not take into account the mutual influence of the components, and therefore there is some discrepancy with experimental data. Based on this, it is proposed to improve the formula by introducing an experimental complex coefficient into it, which takes into account the mutual influence of concrete and fiber, the presence of a cement stone contact zone with improved properties between them, and several other possible factors. At the same time, it is proposed that different types of fiber assign their own coefficient, for example, for polypropylene fiber it is 28,5 [10]. Comparison of the calculated data with experimental data indicates minor discrepancies between them, which confirms the validity of the applied approach. Thus, the formula (2) can be used to determine the elastic modulus of fiber-reinforced concrete:

$$
E_{f b}=\mu_{b} E_{b}+\phi \mu_{f} E_{f}
$$

where $E_{b}$ and $E_{f}$ - elastic modulus of concrete and fiber; $\mu_{b}$ and $\mu_{f}$ - the volume fractions of concrete and fiber in the composite; $\varphi$ - the experimental complex coefficient.

The load at point $\mathrm{C}$ can be found from the known formula for the flexural strength of a concrete (formula 3):

$$
P_{c}=\frac{2 b h^{2} R_{f b}}{3 l_{o}}
$$

where $R_{f b}$ - strength of fiber-reinforced concrete; $b, h$ - sample width and height.

At the same time, the «rule of mixtures» can be applied to calculate the strength, and if the destruction occurs as a result of pulling fibers from the matrix, as in this case, then the calculations are carried out according to the formula (4): 


$$
R_{f b}=\frac{2 \tau l_{f} \mu_{f}}{d}+3,5 R_{k 3} \mu_{f}+R_{b}\left(1-4,5 \mu_{f}\right)
$$

where $\tau$-adhesion strength of the fibers to the matrix; $l_{f}$ - fiber length; $\mu_{f}$ - fiber volume fraction; $d$ - fiber diameter; $R_{b}, R_{f}$ и $R_{\text {кз }}$ - strength of concrete, fiber and the contact zone at the «fiber-matrix» interface.

The strength of the concrete contact zone is determined by the following formula (5):

$$
R_{\kappa 3}=1,4 R_{b}
$$

However, in this case, when low-modulus fibers are used, in the formulas given, the term that determines the contribution of the fiber should be excluded, since it is exhausted only by the modification of the structure of the cement stone of the contact zone (formula 6):

$$
R_{f b}=3,5 R_{k 3} \mu_{f}+R_{b}\left(1-4,5 \mu_{f}\right)
$$

To determine the coordinate corresponding to point $\mathrm{C}$ along the axis of deflections, formula (7) is proposed, obtained by expressing this value from equation (1) after making some changes related to the fact that the zone of plastic deformation is currently being considered:

$$
f_{C}=\frac{P_{C} l_{o}^{3}}{48 E_{f b}^{1} I}
$$

where $E_{f b}^{1}$ - deformation modulus of fiber-reinforced concrete, determined by the formula (8):

$$
E_{f b}^{1}=v_{f} E_{f b}
$$

where $v_{f}$ - coefficient of elastic-plasticity at the moment preceding the destruction of fiberreinforced concrete.

It is known that when determining the deformation modulus (elastic-plasticity modulus) of concrete, the value (v) varies from 1,0 (when the material works elastic) to 0,15 (at the moment preceding destruction). The use of low-modulus fibers almost does not affect the behavior of fiber-reinforced concrete under load in the elastic and elastoplastic stages of deformation, therefore, for such fiber-reinforced concrete, it is proposed to take the coefficient of elastic-plasticity in the range of $0,8-0,9$, depending on the amount of reinforcement.

When constructing the $\mathrm{CD}$ line, it is necessary to take into account that when the maximum load at point $C$ is reached, the main crack in the sample passes through the entire working section, and the participation of the matrix in the further process practically stops. The perception of loads in the descending part of the diagram is provided only by the strength of adhesion of the fibers to the matrix in the process of their stretching or by the intrinsic strength of the fibers, when their bond with the matrix is continues until destruction. At the same time, it is obvious that the load will decrease from the highest point $C$ to zero. Thus, only the value of the sample deflection corresponding to point $\mathrm{D}$ is still unknown, which can be determined by the formula (9):

$$
f_{D}=2 \frac{\frac{l_{f}^{2} \tau b h \mu_{f}}{6 d}}{P_{C}}+f_{C}
$$


In the proposed dependencies, arguments that determine the properties of fibers can be noted: length, diameter, elastic modulus, volumetric content in the composite and their adhesion to the matrix. Most of the listed values are reference data, with the exception of the fiber-matrix bond characteristic. Reference data on the adhesion of fibers to the matrix are scarce and it is proposed to determine this characteristic experimentally separately for each type of fiber. To determine the adhesion strength of the fibers with the matrix, can be used a special calculation and experimental technique [11-13], improved during the present study. In this case, it is required to make several series of fiber-reinforced concrete specimensbeams from cement paste of normal thickness and test them for tensile strength, while recording diagrams of the dependence of specimen deflections on applied loads in accordance with the requirements of GOST 29167. Specimens must be made sequentially, increasing from one series to another the fiber consumption with the smallest possible step.

During this study, were made and tested specimens-beams with dimensions of $7 \times 7 \times 28$ $\mathrm{cm}$. During the study, it was found that the normal thickness of the cement paste is $29,5 \%$. The step with an increase in the consumption of polypropylene fibers in the range from 0 to $0,5 \%$ was $0,05 \%$, and in the range of consumptions from 0,5 to $1,5 \%$ it was increased to $0,1 \%$ by volume. In accordance with the proposed technique, on the obtained deformation diagrams by their superposition, the intersection point was identified, at which the values of the loads taken by concrete and fiber-reinforced concrete are equal to each other. Thus, to determine the adhesion strength of the fibers with the matrix, it became possible to use the formula (10):

$$
\tau=\frac{3 P l d_{f}}{4 b h^{2} l_{f} \mu_{f}}
$$

where $\mu_{f}$ - volume fraction of the fiber at which the loads received by the matrix and the fibers are equal; $P$ - load corresponding to the point of intersection of the deformation diagrams; $b$ - sample width; $h$ - sample height; $l$ - test base.

By substituting the numerical values into the formula (10), the adhesion strength of the polypropylene fibers with the matrix $\tau=0,5 \mathrm{MPa}$ used during the experiment was determined.

As an example of modeling the behavior of fiber-reinforced concrete under load, the process of constructing a diagram of deformation of a fiber-concrete sample using polypropylene fiber, at its consumption of $0,5 \%$ and $1,0 \%$ by volume, is considered. The distance between the points of application of the load in the bending test (base) is $266 \mathrm{~mm}$, in the lower (stretched) face of the specimen there is an initial notch with a depth of $25 \mathrm{~mm}$. The dimensions of the samples for modeling are chosen in such a way that they repeat the process of experimental research and it is possible to assess the convergence of the calculated and experimental results.

At the beginning of the construction of the diagram, the zone of elastic deformations should be considered. It is known that such deformations are characterized by a straight line, and the angle of its slope depends on the elastic modulus of fiber-reinforced concrete, which is determined by formula (2).

Considering that the process of microcracking in fiber-reinforced concrete, regardless of the type and consumption of fibers, begins at the same deflection as the unreinforced sample $\left(f_{T}=0,038 \mathrm{~mm}\right)$, it is possible, using formula (1), to find the load corresponding to the point $\mathrm{T}$, which will be $2,275 \mathrm{kN}$. In this case, the moment of inertia for a rectangular working section of the sample was calculated by formula (11):

$$
I=\frac{b h^{3}}{12}
$$


The load and deflection obtained in this way represent the coordinates of the point where the action of elastic deformations ends and the beginning of the formation of the main crack (point $\mathrm{T}$ ). The load at point $\mathrm{C}$ can be determined by formula (3) taking into account formula (6). Taking into account the above data, the maximum load acting on the sample during its testing (coordinate of point $\mathrm{C}$ along the vertical axis) was $2,415 \mathrm{kN}$. The sample deflection at point $\mathrm{D}\left(f_{D}\right)$ can be determined from (11). As a result of the logarithmic approximation of the obtained segment $C D$, we obtain a smooth curved line of the descending branch of the calculated diagram. The diagrams built according to the calculated characteristics are shown in figure 5 .

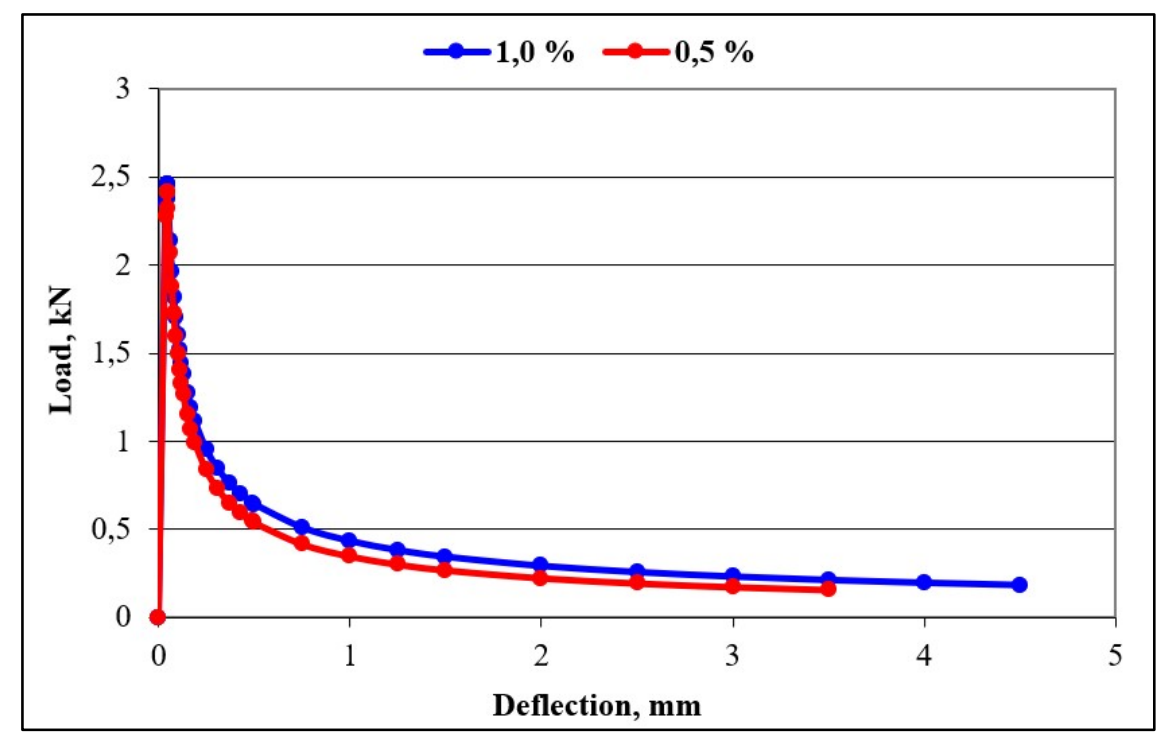

Fig. 5. Estimated diagrams of deformation and destruction of fiber-reinforced concrete reinforced with low-modulus polypropylene fiber.

Table 2 shows the numerical values of the characteristics of crack resistance and elastic modules obtained using the above diagrams.

Table 2. Characteristics of crack resistance and elastic modules of fiber-concrete specimens reinforced with polypropylene fibers.

\begin{tabular}{|c|c|c|}
\hline \multirow{2}{*}{ Crack resistance characteristic } & \multicolumn{2}{|c|}{ Volumetric content of fiber, $\%$} \\
\hline & 0,5 & 1,0 \\
\hline $\begin{array}{l}G^{*}{ }_{i} \text { - conditional specific energy consumption for } \\
\text { static destruction until the moment the main crack } \\
\text { starts to move, } \mathrm{J} / \mathrm{m}^{2}\end{array}$ & 21,6 & 22,2 \\
\hline $\begin{array}{c}G_{f}^{*}-\text { conditional specific energy consumption for } \\
\text { static destruction, } \mathrm{J} / \mathrm{m}^{2}\end{array}$ & 401,1 & 605,5 \\
\hline $\begin{array}{l}K_{c}^{*} \text { - conditional critical stress intensity factor, } \\
\qquad \mathrm{MPa} \cdot \mathrm{m}^{0,5}\end{array}$ & 0,81 & 0,83 \\
\hline Flexural strength, $\mathrm{MPa}$ & 6,2 & 6,4 \\
\hline Elastic modulus, $\mathrm{MPa} * 10^{3}$ & 38,6 & 40,2 \\
\hline
\end{tabular}




\section{Conclusions}

The presented diagrams show the nature of the behavior of fiber-reinforced concrete under load up to destruction and in this sense fundamentally coincide with the diagrams obtained during preliminary experiments and given in the technical literature, which confirms the correctness of the chosen approaches and the validity of the proposed assumptions.

\section{References}

1. D.N. Korotkih, Zakonomernosti razrusheniya struktury vysokoprochnyh cementnyh betonov na osnove analiza polnyh ravnovesnyh diagramm ih deformirovaniya, Vestnik VolgGASU, Seriya: Stroitel'stvo i arhitektura, v. 26(45), pp. 54-62 (2012).

2. D.A. Panteleev, Deformativnye i prochnostnye harakteristiki poliarmirovannogo fibrobetona, Izvestiya KGASU, v. 3(33), pp. 133-139 (2015).

3. D.N. Korotkih, A.V. Ushakov Harakteristika pokazatelej razrusheniya vysokoprochnyh betonov na osnove analiza polnyh ravnovesnyh diagramm ih deformirovaniya, Vestnik Central'nogo regional'nogo otdeleniya RAASN, v. 10, pp. 76-89 (2011).

4. M.I. ZHavoronkov Metodika opredeleniya energeticheskih i silovyh harakteristik razrusheniya fibrobetona, Vestnik grazhdanskih inzhenerov, v. 6(47), pp. 155-160 (2014).

5. YU.V. Puharenko Principy formirovaniya struktury i prognozirovanie prochnosti fibrobetonov, Stroitel'nye materialy, v. 10(598), pp. 47-50 (2004).

6. YU.V. Puharenko, V.YU. Golubev O vyazkosti razrusheniya fibrobetona, Vestnik grazhdanskih inzhenerov, v. 3, pp. 80-83 (2008).

7. YU.V. Puharenko, D.A. Panteleev, M.I. ZHavoronkov Opredelenie vklada fibry v formirovanie prochnosti stalefibrobetona, Vestnik grazhdanskih inzhenerov, v. 1(60), pp. 172-176 (2017).

8. M.I. ZHavoronkov Opredelenie harakteristik razrusheniya i modulya uprugosti fibrobetona, Izvestiya KGASU, v. 3(33), pp. 114-120 (2015).

9. YU.V. Puharenko, D.A. Panteleev, M.I. ZHavoronkov Diagrammy deformirovaniya cementnyh kompozitov, armirovannyh stal'noj provolochnoj fibroj, Academia. Arhitektura i stroitel'stvo, v. 2, pp. 143-147 (2018).

10. YU.V. Puharenko, U.H. Magdeev, V.I. Morozov, D.A. Panteleev Prochnost' i deformativnost' poliarmirovannogo fibrobetona s primeneniem amorfnoj metallicheskoj fibry, Academia. Arhitektura i stroitel'stvo, v. 1, pp. 107-111 (2016).

11. YU.V. Puharenko, D.A. Panteleev, M.I. ZHavoronkov Metody opredeleniya harakteristik treshchinostojkosti fibrobetona, Fundamental'nye, poiskovye i prikladnye issledovaniya RAASN po nauchnomu obespecheniyu razvitiyu arhitektury, gradostroitel'stva i stroitel'noj otrasli RF v 2018 godu: Sb. nauch. tr. RAASN., v. 2, pp. 448-457 (2019).

12. YU.V. Puharenko, V.I. Morozov, D.A. Panteleev, M.I. ZHavoronkov Diagrammy razrusheniya cementnyh kompozitov, armirovannyh amorfnometallicheskoj fibroj, Ekspert: teoriya i praktika, v. 3(6), pp. 50-55 (2020).

13. M.P. Kostrikin Harakter i stepen' vzaimodejstviya sinteticheskoj makrofibry s cementnym kamnem, Vestnik grazhdanskih inzhenerov, v. 4(69), pp. 116-120 (2018). 